\title{
Karabuğdayın Fitokimyası, Farmakolojisi ve Biyofonksiyonel Özellikleri
}

\author{
Cansu İnanır ${ }^{1}$, Sevil Albayrak ${ }^{2}$, Lütfiye Ekici ${ }^{*}$, \\ ${ }^{1}$ Erciyes Üniversitesi Mühendislik Fakültesi Gıda Mühendisliği Bölümü, Kayseri, Türkiye (ORCID: 0000-0002-4748-954X; 0000-0002-2216- \\ 9128) \\ ${ }^{2}$ Erciyes Üniversitesi Fen Fakültesi, Biyoloji Bölümü, Kayseri, Türkiye (ORCID: 0000-0002-0253-3746)
}

(İlk Geliş Tarihi 21 Haziran 2019 ve Kabul Tarihi 20 Temmuz 2019)

(DOI: $10.31590 /$ ejosat.580742)

\begin{abstract}
ATIF/REFERENCE: İnanır, C., Albayrak, S. \& Ekici, L. (2019). Karabuğdayın Fitokimyası, Farmakolojisi ve Biyofonksiyonel Özellikleri. Avrupa Bilim ve Teknoloji Dergisi, (16), 713-722.

$\ddot{O} \mathbf{z}$

Karabuğday, Polygonaceae familyasına ait çok eski çağlardan beri yetiştirilen bir üründür. Fagopyrum cinsi iki önemli karabuğday türü içermektedir: Yaygın karabuğday (Fagopyrum esculentum Moench ve Tatar karabuğdayı (Fagopyrum tataricum Gaertn.). Bu iki önemli tür dışında Fagopyrum cymosum türü ise çok yaygın yetiştirilmemekle birlikte özellikle Çin tıbbında önemli bir yere sahiptir. Karabuğday, sahip olduğu önemli besin içeriği ve sağlık üzerine yararlı etkileri sebebiyle son yıllarda alternatif bir ürün olarak diyete dahil edilmektedir. Karabuğday tohumları, diğer tahıllarla kıyaslandığında sahip olduğu farklılıklar nedeniyle pseudo-tahıl grubu içerisindedir. Bu farklılıklardan en önemlisi, karabuğdayın diğer tahıllar gibi tek çenekli olmayıp, çift çenekli bir bitki olmasıdır. Karabuğday taneleri ve diğer dokular çok sayıda nutrasötik bileşik içermektedir. Karabuğday protein, polisakkarit, diyet lifi, lipit, polifenollerden özellikle rutin ve mikro besin (mineraller ve vitaminler) içeriği ile dikkat çekici bir tahıldır. Ayrıca son yıllarda karabuğday tohumlarının çimlendirilmesi ile besleyici değerinin artırılabileceği fikri önem kazanmaktadır. Karabuğdayın antioksidan, antitümör, antidiyabetik, antibakteriyel gibi birçok farmakolojik özelliğe sahip olduğu bildirilmiştir. Bu özellikler sahip oldukları zengin içeriklerine atfedilmektedir. Sağlık yararları nedeni ile son yıllarda karabuğdaya olan talep artmaktadır. Bu derlemede karabuğdayın genel kullanımı, kimyasal bileşenleri ve farmakolojik özellikleri ile ilgili araştırmalar özetlenmiştir.
\end{abstract}

Anahtar Kelimeler: Pseudo-tahıl, nutrasötik bileşen, rutin, çimlenme

\section{Phytochemistry, Pharmacological and Biofunctional Properties of Buckwheat}

\begin{abstract}
Fagopyrum belongs to family Polygonaceae that grown since ancient years. The genus Fagopyrum contains two important buckwheat species: the common buckwheat (Fagopyrum esculentum Moench) and Tatar buckwheat (Fagopyrum tataricum Gaertn.). Apart from these two important species, the species Fagopyrum cymosum is not widely cultivated, but it has an important place in Chinese medicine. Buckwheat has been included in the diet as an alternative product in recent years due to its important nutritional content and beneficial effects on health. Buckwheat seeds are in the pseudo-cereal group due to their differences compared to other cereals. The most important of these differences is that buckwheat is not monocotyledon like other cereals, it is a dicotyledon. Buckwheat grains and other tissues contain a large number of nutraceutical compounds. Buckwheat is a remarkable grain with protein, polysaccharide, dietary fiber, lipids,
\end{abstract}

1 Sorumlu Yazar: Erciyes Üniversitesi Mühendislik Fakültesi Gida Mühendisliği Bölümü, Kayseri, ORCID: 0000-0002-2216-9128, lutfiyed@erciyes.edu.tr 


\section{Avrupa Bilim ve Teknoloji Dergisi}

polyphenols, especially with routine and micronutrient (minerals and vitamins) content. In addition, the idea that the nutritional value can be increased by germinating buckwheat seeds has gained importance in recent years. It has been reported that buchwheat have many pharmacological properties such as antioxidant, antitumor, antidiabetic, antibacterial. These properties are attributed to its rich contents. Due to its health benefits, demand for buckwheat has been increasing in recent years. In this review, the researches on the general usage of buckwheat, its chemical components and pharmacological properties are summarized

Keywords: Pseudo-cereal, nutraceutical component, rutin, germination

\section{Giriş}

Polygonaceae familyası, Fagopyrum cinsine ait karabuğday, dünyada yaygın olarak tüketilen bir gıda olmuştur. Fagopyrum cinsinin, dünyanın farklı bölgelerine dağılmış yaklaşık 15 türe sahip olduğu bilinmektedir (Guo, Xiaona, Zhu, Zhang ve Yao, 2010). Fakat bunlardan Yaygın karabuğday (Fagopyrum esculentum Moench) ve Tatar karabuğdayı (Fagopyrum tataricum Gaertn.) dünya çapında tarımsal öneme sahip, en çok yetiştirilen ve gıda kaynağı olarak kullanılan iki türüdür. Bu iki önemli türe kıyasla daha az bilinen ve yetiştirilen, özellikle Asya'da geleneksel kullanıma sahip, uzun karabuğday olarak da bilinen tür ise Fagopyrum cymosum'dur (Kılıç ve Elmac1, 2018).

Yaygın karabuğday kuzey yarımkürenin ılıman bölgelerinde yetişirken, Tatar karabuğdayı ise temel olarak daha yüksek irtifa bölgelerinin bir ürünüdür (Ji ve ark., 2019; Molinari ve ark., 2018) Yaygın karabuğday türü; daha büyük tohum yapısı, kolay soyulabilen kabuk ve lezzetli bir tada sahip olmasından dolayı Tatar karabuğdayından daha çok tüketilmektedir. Aksine, Tatar karabuğdayı ise daha küçük bir tohuma, zor soyulan kabuğa ve acı bir tada sahip olması ile karakterize edilmektedir (Dizlek, Özer, İnanç ve Gül, 2009).

Kısa mevsim mahsulü olan karabuğday, düşük verimli veya asitli topraklarda iyi yetişmektedir. Hızlı büyüyen ve tek yıllık bitki sınıfına girmektedir. Karabuğday bitkisi çiçekleri genellikle beyaz renktedir (Şekil 1). Tozlayıcıların varlığı verimi büyük ölçüde arttırmaktadır. Karabuğday, ekiminin kolay olmasının (Ahmed ve ark., 2014) yanı sıra sadece 10-12 haftalık bir büyüme periyoduna sahiptir. Karabuğday bitkisinin boyu yetiştirme koşullarına ve ortam şartlarına göre 75 ile 125 cm arasında değişmektedir (Dizlek, Özer, İnanç ve Gül, 2009). Karabuğday, fenolik içeriği ve taşıdığı antioksidan özelliklerine ilaveten depolama süresinin uzun olması gibi bazı avantajlara sahiptir (Ahmed ve ark., 2014).

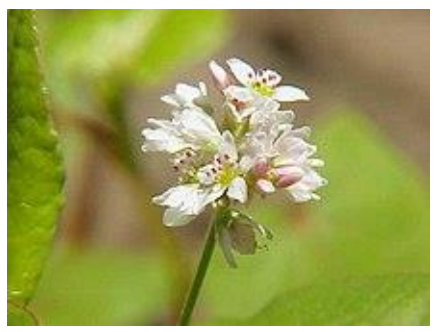

Şekil 1. Karabuğday bitkisi (Anonim, 2019)

Son yıllarda geliştirilen glutensiz ekmek, makarna ve bisküvi gibi gıda ürünleri tahıl benzeri olarak sınıflandırılan pseudotahıllardan üretilmektedir. Amarant, kinoa ve karabuğday pseudo-tahıl sınıfına ait gıdalara örnek verilebilir (Yıldız ve Yalçın, 2013). Karabuğday tohumlarının yapısı tahıllara benzemekle birlikte, bazı farklılıkları dolayısıyla pseudo-tahıl grubuna dahil edilmektedir (Mir, Riar ve Singh, 2018). Bu farklılıklardan en önemlisi, karabuğdayın diğer tahıllar gibi tek çenekli olmayıp, çift çenekli bir bitki olmasıdır. Karabuğday tohumları tahıllarda olduğu gibi nişastalı endosperm içerir. Karabuğday kahverengi ve üçgen biçimli tohumlara sahiptir (Şekil 2). Bu tohumların çevresi perikarp adı verilen meyve kabuğuyla kaplıdır. Sert lifli bir yapıya sahip olan perikarp tohum kabuğunu, endospermi ve embriyoyu sıkıca çevrelemektedir. Ek olarak, alevron tabakası nişasta içeren endospermi kuşatmaktadır. Endosperm hücreleri, ince hücre duvarlarına sahiptir ve esas olarak nişastadan oluşmaktadır. Bir karabuğday tohumundaki embriyo, endospermin merkezinde bulunur ve iki kotiledon içermektedir (Liu, Wang, Cao, Fan ve Wang, 2016). Karabuğdayın rengi ve lezzeti en önemli kalite kriterlerini oluşturmaktadır. Karabuğday tohumları ilk hasat edildiğinde yeşil iken, zamanla eski taneler kırmızı kahverengi bir renk almaktadır. Yeni hasat edilmiş tohumlar alışılagelmiş karabuğday tadına sahiptir. Eski tanelerde zamanla acı bir tat oluşmaktadır (Dizlek, Özer, İnanç ve Gül, 2009).

Karabuğdayın Türkiye'de kültürü yapılmazken, dünyada birçok ülkede yetiştirilmektedir (Kan, 2011). FAOSTAT (Food and Agricultural Organization of The United Nations, Birleşmiş Milletler Gıda ve Tarım Örgütü) verilerine göre 2017 yılındaki karabuğday üretimi dünya çapında toplam 3.827.748 tondur. Verilere göre 2017 yılındaki karabuğday üretimi Asya'da 1.619.429 tondur. Asya bölgesi, dünyadaki karabuğday üretimin yaklaşık \%40’ını oluşturmaktadır. Asya ülkeleri arasında en fazla üretim 1.447.292 ton ile Çin karabuğdayın en büyük üreticisi konumundadır. Çin’i sırası ile Rusya ve Ukrayna takip etmektedir (FAOSTAT, 2019). 


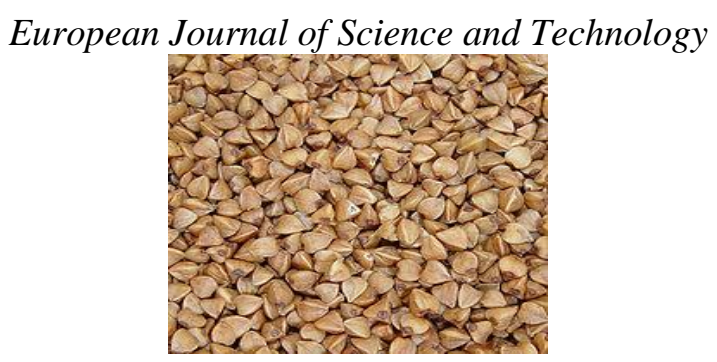

Şekil 2. Karabuğday tohumlarl (Anonim, 2019)

Bu derlemede, karabuğdayın başlıca özellikleri, bileşimi, sahip olduğu farmakolojik özellikleri ve sağlık üzerine olumlu etkileri ele alınmaktadır.

\section{Geleneksel Kullanımı}

Tarihsel olarak karabuğday, 20. yüzyılda Batı ülkelerinde buğday kaynaklı rekabet nedeniyle ihmal edilmiş olmasına rağmen, 17. ve 19. yüzyıllarda çok popüler bir gıda olarak tüketilmekteydi. Karabuğday Orta Asya kökenli bir bitkidir. Karabuğdayın kökenine bakıldığında benimsenen en yaygın fikir Çin’de bulunan Yunnan’da yetiştirildiği yönündedir. Karabuğday, daha sonra soğuk iklime sahip bölgelere yayılmıştır. Karabuğdayın zorlu iklim koşullarında bile yetiştirilebilmesi ve zengin besin içeriği dolayısıyla gerek gıda olarak gerekse de geleneksel tıpta kullanımı zamanla artmıştır. Karabuğday tohumları sahip olduğu kaliteli proteinleri, yoğun fenolik bileşikleri ve iyi dengelenmiş esansiyel amino asitleri ve mineralleri nedeniyle potansiyel bir "fonksiyonel gıda" olarak dünya çapında tüketilmektedir (Dizlek, Özer, İnanç ve Gül, 2009). Hem Yaygın hem de Tatar karabuğday türü geleneksel tıpta çeşitli tıbbi amaçlar için kullanılmıştır. Geleneksel Çin tıbbında Yaygın karabuğday türü tohumları dalağı canlandırma (yenileme) ve inmeyi azaltma yeteneğine sahip bir bitki olarak değerlendirilmektedir. Karabuğday tanelerinin haricinde Tatar karabuğday kökü de romatizmal hastalıklar ve kanser gibi kronik hastalıkların tedavisi için geleneksel Çin tıbbının bir parçasıdır. Ayrıca karabuğdayın antitümör, antihipertansif, antienflamatuvar, antioksidan, hipoglisemik, yorgunluk önleyici ve hepatoprotektif özelliklere sahip olduğu belirtilmektedir. Karabuğday İngiliz Bitkisel Farmakopesi (ilaçlar kitabı)' nde ise hemorajik ve hipotansif etkileri olan ilaç olarak yer almaktadır. Kore'de ise geleneksel olarak anti-enflamatuvar, ateş düşürücü ve detoksifikiye edici ajan olarak kullanıldığı aktarılmaktadır. Geleneksel tıp haricinde sahip olduğu sağlık etkileri nedeni ile farklı kullanımlara da sahiptir. Örneğin, karabuğday çayı Asya ve Avrupa ülkelerinde tüketilen popüler bir üründür (Jing ve ark., 2016).

\section{Karabuğdayın bileşimi}

Karabuğdayın sahip olduğu bileşenlerin miktarları türe ve yetiştirildiği çevre faktörlerine bağlı olarak değişiklik gösterebilmektedir. Karabuğday unu bileşiminin tüm dünyada yaygın olarak tüketilen tahıllar ile kıyaslandığı veriler Tablo 1'de gösterilmiştir (Ahmed ve ark., 2014).

Tablo 1. Karabuğday ve diğer tahılların bileşimi (mg/g kuru ă̆ırlık) (Ahmed ve ark., 2014)

\begin{tabular}{lcccccc}
\hline Tahıl & Protein & Kül & Lipit & Çözünür lif & Çözünmez lif & Toplam lif \\
\hline Buğday & 115 & 17 & 10 & 10 & 15 & 25 \\
Yaygın karabuğday & 110 & 26 & 34 & 12 & 53 & 65 \\
Tatar karabuğdayı & 103 & 18 & 25 & 5 & 58 & 63 \\
Yulaf & 126 & 18 & 71 & 33 & 49 & 82 \\
Çavdar & 117 & 15 & 18 & 36 & 100 & 136 \\
\hline
\end{tabular}

Karabuğday tohumlarında, protein içeriğinin çeşide bağlı olarak 85-188 mg/g arasında değiştiği belirlenmiştir. Karabuğdaydaki protein içeriğinin pirinç, sorgum, darı ve mısırdan oldukça yüksek olduğu tespit edilmiştir. Karabuğday proteinleri, albümin, globülin, prolamin ve glutelin içermektedir. Tahıllarda, başlıca depolama proteinleri prolaminler iken karabuğdayda çoğunlukla bu görevi globulinler üstlenmektedir. Karabuğday tanelerinin ana depolama proteini $13 \mathrm{~S}$ globülindir. Sahip olduğu globülinler asidik ve bazik polipeptitlerden oluşan disülfit bağlı birimlerle birlikte bir heksametrik yapıya sahiptir. Karabuğday tohumlarının \% 64,5 oranında globülin, \%12,5 albumin, \%8,0 glutelin ve \%2,9 prolamin içerdiği belirlenmiştir. Karabuğday tohumları, çölyak hastaları için toksik olan prolamini iz miktarda içermesi nedeniyle bu hastalar ve gluten intoleransı olan kişiler tarafından rahatça tüketilebilmektedir. Üretilen glutensiz ürünlerin besleyici kalitesine bakıldığında çoğunun besleyici açıdan güçlendirilmemesi nedeniyle tiyamin, riboflavin, demir ve folatı düşük miktarlarda içerdiği belirlenmiştir. Glutensiz beslenen çölyak hastası kadınların \% $\%$, \%44 ve \%31'inde lif, demir ve kalsiyumun yetersiz olduğu saptanmıștır. Buna benzer çalışmalar ile piyasadaki glutensiz gidaların besleyici değerlerinde iyileştirmeye gidilmesi gerekliliği ortaya çıkmaktadır. Bu nedenle besleyici değeri yüksek, önemli bir gıda olarak kabul edilen karabuğdayın tüketiminin artırılması ve gıdaların karabuğday ile zenginleştirilmesi önem taşımaktadır (Giménez-Bastida, Piskuła ve Zieliński, 2015; Kılıç ve Elmac1, 2018). 


\section{Avrupa Bilim ve Teknoloji Dergisi}

İyi dengelenmiş amino asit bileşimi nedeniyle, karabuğday proteinleri yüksek biyolojik değere sahiptir. Karabuğdayın esansiyel amino asit içeriği Tablo 2'de diğer tahıllarla kıyaslanmıştır (Hayıt ve Gül, 2015). Tahıl tanelerinde lizin miktarı sınırlıdır, triptofan ve treonin seviyeleri yetersizdir. Tahıl taneleri ile karşılaştırıldığında, karabuğday proteini ise yüksek lizin içeriğine sahiptir. Karabuğday proteinleri arginin bakımından zengin olsa da treonin ve lösin içeriği düşüktür. Ayrıca karabuğday, diğer tahıllara kıyasla yüksek seviyede aspartik asit $(\%$ 11,3) ve düşük seviyede prolin $(\%$ 3,9) içermektedir. Karabuğday taneleri, çölyak hastaları için yüksek miktarda esansiyel amino asit içeren değerli bir diyet proteini kaynağı oluşturabilir. Baklagillerin fitik asit, tanen ve proteaz inhibitörü gibi anti besinsel faktörleri içerdiği bilinmektedir. Bu anti besinsel öğelerin varlığı protein, nişasta ve mineraller gibi besinlerin emilimini engellediği aynı zamanda bu besinlerin sindirilebilirliğini de azalttığı yapılan çalışmalar ile belirlenmiştir. Besinler ile alınan tanenlerin proteinler ile etkileşimleri sonucu oluşan tanen-protein kompleksinin büyümenin baskılanmasından ve düşük protein sindirilebilirliğinden sorumlu olduğu düşünülmektedir. Önemli miktarda protein içermesine ve dengeli amino asit içeriğgine rağmen karabuğday proteini ile ilgili en büyük problem, sindirilebilirliğinin düşük olmasıdır. Yaygın karabuğdayda düşük sindirilebilirlik, tripsin inhibitörleri gibi proteaz inhibitörleri ve tanenlerden kaynaklanmaktadır. Karabuğday tohumlarının çimlenmesi proteaz inhibitörlerinin aktivitesinin önemli ölçüde azalmasına sebep olmaktadır. Bu nedenle çimlendirilmiş karabuğday protein bakımından önemli bir gıda kaynağı olarak kabul edilebilir (Ahmed ve ark., 2014). Tiamin bağlayıcı proteinler (TBP), bitkilerde $\mathrm{B}_{1}$ (tiamin) vitamini taşıyıcıları olarak işlev gördüklerinden teknolojik işlemler sırasında $B_{1}$ vitaminin stabilitesini geliştirebilmektedir. Tiamin bağlayıcı proteinler (TBP) karabuğday tanelerinin önemli bir kısmını oluşturmaktadır (Christa ve Soral-Smietana, 2008; Mitsunaga, Matsuda, Shimizu ve Iwashima, 1986; Wijngaard ve Arendt, 2006).

Tablo 2. Karabuğday esansiyel amino asitlerinin diğer tahıllarla karşılaştırılması (protein yüzdesi olarak) (Hayıt ve Gül, 2015)

\begin{tabular}{lcccc}
\hline Tahıl & Lizin & Metiyonin & Triptofan & Lösin \\
\hline Karabuğday & 5,9 & 3,7 & 1,4 & 5,8 \\
Buğday & 2,6 & 3,5 & 1,2 & 6,3 \\
Pirinç & 3,8 & 3,0 & 1,0 & 8,2 \\
Misır & 1,9 & 3,2 & 0,6 & 13,0 \\
\hline
\end{tabular}

Nişasta, karabuğday tanelerinin en önemli depolama bileşenlerindendir. Bitki büyümesi için gerekli enerjiyi sağlamada kullanılmak üzere endosperm kısmında birikir. Bütün karabuğday tanesinde nişasta içeriği, kuru ağırlığın \% 59 ile \% 70'i arasında değişmektedir. Nişasta içeriğinin farklı iklim ve ekim koşulları ile değiş̧iklik gösterdiği belirlenmiştir. Karabuğday tanelerinden izole edilen nişasta bileşiminin tahıl nişastalarından farklı olduğu tespit edilmiştir. Karabuğday nişastası granüllerinin amiloz içeriği \% 15 ile \% 52 arasında değişmektedir. Beslenme açısından bakıldığında hızlı sindirilebilir nişasta, yavaş sindirilebilir nişasta ve dirençli nişasta (RS) olmak üzere üç farklı nişasta fraksiyonu içermektedir. Dirençli nişasta; ince bağırsakta emilmeden, kalın bağırsaktaki mikroflora tarafindan kısmen veya tamamen fermente edilebildiğinden, etkileri diyet liflerine benzemektedir. Dirençli nişasta içeriği yüksek olan gidaların glisemik indeksleri düşük kabul edilmektedir. Düşük glisemik indeksli gıdalar, kan şekerinin düzenlenmesi ve obezitenin önlemesinde etkili olarak kalp hastalıkları riskini azalttığından (Sieri ve Krogh, 2017) karabuğdayın kronik hastalıkların tedavisinde kullanılabileceği fikri benimsenmektedir. Pişmemiş karabuğday taneciklerinde, RS toplam nişastanın \% 33-38'ini oluştururken pişirme sonrasında sadece \% 7-10 arasında olduğu saptanmıştır (Wijngaard ve Arendt, 2006). Karabuğdayda bulunan nişastanın sindirilebilirliği düşük olduğundan, çimlenme esnasında enzimler tarafindan parçalanarak sindirilebilirliğinin büyük ölçüde iyileştirilebileceği düşünülmektedir (Yiming ve ark., 2015).

Karabuğday embriyolarında bulunan çözünür karbonhidratlar arasında D chiro-inositol, myo-inositol, galaktinol ve rafinoz bulunmaktadır. Çözünür karbonhidratların embriyoda yoğunlaştı̆̆ı, endospermde düşük bir konsantrasyona sahip olduğu, ancak kepekte daha yüksek olduğu gözlenmiştir (Ahmed ve ark., 2014; Zhu, 2016a). Yapılan çalışmalar D-chiro-inositol' un kan glukoz seviyesini ve insülin aktivitesini olumlu yönde etkileyebileceğini göstermektedir (Mancini ve ark., 2016). Fagopyritol, D-chiro inositol'ün galaktoz ile birleşmesiyle oluşan spesifik bir karbonhidrattır. İlk olarak karabuğdayda tanımlandığı için adını karabuğdayın Latince adından almaktadır. Fagopyritol, karabuğday tohumlarının embriyo ve alevron dokularında biriken D-chiro inositol mono-, di- ve trigalaktosil türevleridir. Diyetle birlikte alımı ile besin takviyesi olarak önemli sayılmaktadır. Konsantrasyonu endospermde düşüktür. Karabuğdaydaki toplam içeriği \% 1 ile \% 6 arasında değişmektedir. D-chiro inositol türevi olan Fagopyritol $\mathrm{A}_{1}$, diyabet ve polikistik over sendromunun tedavisinde kullanılabilecek önemli bir bileşen olarak sayılmaktadır (Macut, Bjekić-Macut, Rahelić ve Doknić, 2017). Fitik asit; proteinlerin yanısıra demir, kalsiyum, magnezyum ve fosfor gibi mineraller ile bağlanarak bunların çözünürlüklerini ve sindirilebilirliklerini azalttığından anti-besin faktörü olarak tanımlanmaktadır (Bayraktar ve Akbulut, 2013). Karabuğdayın içerdiği diyet lifinin önemli özelliklerinden biri de fitik asit içermemesidir (Ahmed ve ark., 2014).

Genel olarak lipitler, tahılların ve pseudo-tahıllarda iz miktarda bulunmakla birlikte, önemli fizyolojik özelliklere sahiptir. Lipitler ayrıca depolanmış tohumların veya unların bozulmasına neden olabileceğinden gıda kalitesinde önemli rol oynamaktadır. Hem Yaygın hem de Tatar karabuğdayı embriyoları önemli miktarlarda lipit içermektedir. Embriyo ortalama \% 6,5 yağ içerirken, endosperm $<\% 0,4$ yağ içeriğine sahiptir (Wijngaard ve Arendt, 2006). Yaygın karabuğday tohumlarının 15-37 mg/g toplam lipit içerdiği belirlenmiş̧ir. Yaygın karabuğdayda bulunan başlıca yağ asitleri palmitik, oleik, linoleik, stearik, linolenik, araşidonik, behenik ve lignoserik asittir. İçerdiği doymamış yağ asitlerinin \% 40'tan fazlasını çoklu doymamış yağ asitleri (PUFA) oluşturmaktadır (Ahmed ve ark., 2014; Dziadek ve ark., 2016).

Mineraller insan vücudundaki çeşitli fizyolojik fonksiyonlar için önemli bileşenlerdir. Yapılan birçok çalışma ile karabuğday tohumlarının esansiyel mineraller için iyi bir kaynak olduğu belirlenmiştir. Karabuğday tohumlarının mineral içeriği Tablo 3 'te verilmiştir. Karabuğday taneleri, potasyum, magnezyum, kalsiyum ve fosfor bakımından zengindir. Karabuğdayda fosfor, potasyum ve magnezyum en çok kepekte, özellikle de öğütülmeden önce çıkarılan kabuklarda yoğunlaşmaktadır (Katar, Olgun ve Turan, 2016). Kabukları endosperm takip etmektedir. Pirinç, buğday unu veya mısır gibi diğer tahıllarla karşılaştırıldığında, karabuğday daha yüksek 


\section{European Journal of Science and Technology}

düzeyde çinko, bakır ve manganez içermektedir. Özellikle bu minerallerin biyoyararlanımı karabuğday ile alımlarında yüksektir. Krom ve selenyum gibi iz elementler ise karabuğdayda düşük seviyelerde tespit edilmiştir (Ahmed ve ark., 2014; Christa ve Soral-Smietana, 2008). Çimlendirme işlemi tahılların kompozisyonlarında değişimlere neden olmaktadır. Nitekim yedi gün çimlendirildikten sonra karabuğday tohumlarının kalsiyum, fosfor, magnezyum ve potasyum içeriklerinin arttığı bildirilmektedir (Pongrac ve ark., 2016).

Vitaminler iz miktarlarda dahi insan vücudunun düzenli çalışması için gerekli olan organik bileşiklerdir. Karabuğday tohumlarının vitamin içeriği Tablo 4'te verilmiştir. Karabuğday taneleri, çoğu tahıldan daha yüksek oranda $\mathrm{B}_{1}$ (tiamin), $\mathrm{B}_{2}$ (riboflavin), $\mathrm{E}$ (tokoferol) ve $B_{3}$ (niasin ve niasinamid) vitaminlerini içermektedir. $B$ vitamini içeriği endosperm ve embriyonun periferik bölümlerinde yoğunlaşmaktadır. Bu nedenle en yüksek miktarda $\mathrm{B}$ vitamini kepekte bulunmaktadır. Genellikle Tatar karabuğday1, $\mathrm{B}_{1}, \mathrm{~B}_{2}$ ve $\mathrm{B}_{3}$ vitaminlerini yüksek oranda içerirken, daha az $\mathrm{E}$ vitamini içermektedir. Tiaminin karabuğday tohumlarındaki tiamin bağlayıcı proteinlere güçlü bir şekilde yapıştı̆̆ bilinmektedir. Tiamin bağlayıcı proteinlere yapışması sayesinde depolama sırasında stabilitesinin ve diyetle alımı ile biyoyararlanımının artırabileceği düşünülmektedir. Çimlendirme işlemi karabuğdayın sadece amino asit ve mineral miktarlarını değiştirmekle kalmayıp, C, $B_{1}$ ve $B_{6}$ vitamini içeriklerini de arttırmaktadır (Ahmed ve ark., 2014; Christa ve Soral-Smietana, 2008; Wijngaard ve Arendt, 2006).

Tablo 3. Karabuğday tohumlarının mineral içeriği (Ylldız ve Yalçın, 2013)

\begin{tabular}{ll}
\hline Mineraller & Miktarı $(\mathrm{mg} / 100 \mathrm{~g})$ \\
\hline Kalsiyum & $11,0-11,6$ \\
Demir & $4,0-17,5$ \\
Magnezyum & $173-390$ \\
Fosfor & $330-426$ \\
Potasyum & $450-470$ \\
Bakır & $0,95-1,2$ \\
Mangan & $3,37-14,3$ \\
Çinko & $0,87-2,8$ \\
\hline
\end{tabular}

Flavonoidler, bitkilerde yaygın olarak bulunan polifenolik bileşiklerdir. Bitki kökenli gıdalarda doğal olarak oluşan 4000'den fazla polifenolik bileşik bulunduğu belirlenmiştir. Karabuğdayda fenolik miktarı kabuk kısmında \% 0,7 iken, kabuğu çıkarılmış tanelerde \% 0,8 seviyelerindedir. Karabuğday tohumlarındaki fenolik içerik ve kompozisyonunun tür, büyüme fazı ve büyüme şartlarından etkilendiği tespit edilmiştir. Tatar karabuğdayının flavonoid içeriği genellikle Yaygın karabuğdayınkinden daha yüksektir. Tatar karabuğday tohumlarında flavonoid içeriği $40 \mathrm{mg} / \mathrm{g}$ iken, Yaygın karabuğday tohumlarının flavonoid içeriğinin 10mg/g olduğu tespit edilmiştir (Ahmed ve ark., 2014). Karabuğday ekstraktında rutin, kuersetin, kampferol-3-rutinosid ve az miktarda flavonol-tri-glikosit gibi dört flavonol glikozit bulunduğu saptanmıştır (Bhinder ve ark., 2019). Karabuğdaydaki ana flavonoid olan rutin, rutinoz eklenmiş bir kuersetin aglikonudur. Karabuğday önemli bir rutin kaynağı olan tek pseudo-tahıldır (Şekil 3). Nitekim yapplan araştırmalarda, karabuğday dışında hiçbir tahıl veya pseudo-tahılda diyet için kaynak oluşturabilecek rutin tespit edilememiştir (Bai ve ark., 2015). İçerdiği kateşinler ve diğer polifenol bileşenler ile bu bileşiklerin potansiyel antioksidan aktiviteleri beslenme açısından son derece önemlidir (Christa ve Soral-Smietana, 2008). Çimlenme sürecinde, karabuğday tohumlarında biyolojik olarak önemli bazı bileşenlerin seviyelerinin arttı̆̆ ve çeşitli dokuların (kotiledon, hipokotil ve kök) ortaya çıktığı belirlenmiş̧tir. Günümüzde karabuğday ve karabuğday filizleri ile ilgili çalışmalar öncelikle flavonoid içerikleri ve bu bileşiklerin sahip olduğu antioksidan aktivitelerine odaklanmaktadır. Çimlenme sürecinde, karabuğday filizlerindeki toplam fenolik ve rutin içeriği ile antioksidan aktivitesinde önemli artışın olduğu tespit edilmiştir (Gullón, Lú-Chau, Moreira, Lema ve Eibes, 2017; Ling ve ark., 2018). Bazı çalışmalar sonucunda çimlenme ile Tatar karabuğdayının kuersetin ve kuersetin glikoziti olan rutin içeriklerinin arttığı gözlemlenmiştir (Ling ve ark., 2018; Yiming ve ark., 2015).

Tablo 4. Karabuğday tanelerinin vitamin içeriği (Ahmed ve ark., 2014)

\begin{tabular}{lc}
\hline Vitamin & $\begin{array}{c}\text { Karabuğdaydaki } \\
\text { seviyesi (mg/g) }\end{array}$ \\
\hline A ( $\beta$-karoten) & 2,1 \\
B $_{1}$ (tiamin) & 4,6 \\
B $_{2}$ (riboflavin) & 1,4 \\
B $_{3}$ (niasin) & 18,0 \\
B $_{5}$ (pantotenik asit) & 10,5 \\
B $_{6}$ & 7,3 \\
C (askorbik asit) & 50,0 \\
E (tokoferol) & 54,6 \\
\hline
\end{tabular}


<smiles>CC1OC(OCC2OC(Oc3c(-c4ccc(O)c(O)c4)oc4cc(O)cc(O)c4c3=O)C(O)C(O)C2O)C(O)C(O)C1O</smiles>

Şekil 3. Karabuğdaydaki önemli fenolik bileşen rutin (Ahmed ve ark., 2014)

\section{Farmakolojik Özellikler}

\subsection{Anti-tümör aktivite}

Karabuğday türlerinden bir tanesi olan Fagopyrum cymosum özellikle Çin tıbbındaki önemli türlerdendir. Akciğer tümörleri de dahil olmak üzere çeşitli akciğer hastalıklarını tedavi etmek için kullanılmaktadır (Wajid, Aslam ve Uzair, 2015). Karabuğdayın içerdiği protein, polifenoller ve fenilpropanoid glikozitler gibi bazı bileşenlerin çeşitli kanser hücreleri üzerinde sitotoksisite gösterdiği belirlenmiştir (Guo, Xiaona, Zhu, Zhang ve Yao, 2010; Zheng ve ark., 2012). İ vitro deneyler ile $F$. cymosum'un yaklaşı 25 ile 40 $\mathrm{g} / \mathrm{mL}$ konsantrasyonunun akciğer, karaciğger, kolon, lökosit ve kemiklerdeki kanser hücrelerinin büyümesini önemli ölçüde engelleyerek sitotoksisite gösterdiği belirlenmiştir. Fakat prostat, serviks, over ve beyin kanser hücrelerinin $F$. cymosum'a duyarlı olmadığ 1 tespit edilmiştir (Chan, 2003). Birçok in vivo ve in vitro çalı̧̧a, Fr4'ün ( $F$. cymosum rizomlarının ekstraktındaki dördüncü fraksiyon), $F$. cymosum'un antiproliferatif aktivitesinden sorumlu ve en umut verici fraksiyon olarak kabul edildiğini ortaya koymaktadır. Fenolik içeriği yüksek olan Fr4, $400 \mathrm{mg} / \mathrm{kg}$ dozda C57BL/6 farelere enjekte edildiğinde Lewis akciğer tümörünün büyümesini önemli ölçüde inhibe ettiği tespit edilmiştir. Ayrıca, Fr4'ün farelerde sarcoma-180 (S180), hepatoma-22 (H22) gibi tümörlerin büyümesini baskılayarak siklofosfamid ile sinerjistik etki gösterdiği ve siklofosfamid miyelosupresyonun yan etkilerini hafifletebileceği belirlenmiştir. Yaygın karabuğday çiçek ve yaprak ektraktlarının (EFBL) tümör hücresi proliferasyonunu önemli ölçüde inhibe ettiği ve H22 hücrelerinin apoptozisini indüklediği saptanmıştır. EBFL'in ayrıca artan GSH-Px ve SOD aktivitesi içeriği ile ilişkili olabilecek S180 tümörünün büyümesini inhibe edebileceği tespit edilmiştir (Jing ve ark., 2016). Yapılan son çalışmalar yeni bir antitümör proteini olan TBWSP31'in, Tatar karabuğdayının suda çözünen ekstraktlarından izole edilebildiğini göstermiştir. TBWSP31'in insanlardaki göğüs kanseri hücre çizgisi Bcap37'deki hücrelerinin apoptoz indüksiyonu yoluyla büyümesini inhibe edebileceği sonucuna varılmıştır (Guo, Xiaona, Zhu, Zhang ve Yao, 2010).

\subsection{Antioksidan aktivite}

Çok sayıda çalışma, polifenol içeriği yüksek olan bitkilerin, gıda ve ekstraktların antioksidan aktivitelerine büyük ölçüde katkıda bulunabileceğini ortaya koymaktadır (Cai, Luo, Sun ve Corke, 2004). Flavonoidler, tanenler, fenolik asitler, kumarinler, stilbenler dahil olmak üzere birçok fenolik bileşiğin, güçlü antioksidan aktiviteye sahip olduğu rapor edilmiştir. Karabuğdayın tıbbi gıda olarak kullanılmasının sebeplerinden biri de içerdiği yüksek miktardaki fenolik bileşiklerdir. Yapılan bir çalıșmada, $0.05 \mathrm{mg} / \mathrm{mL}$ konsantrasyonda, askorbik asit, bütillenmiş hidroksitolüen (BHT) ve rutinin DPPH (1,1-difenil-2-pikrilhidrazil) radikaline karşı sırasıyla \% 92.8, \% 58.8 ve \% 90.4 inhibisyon sergilediği ve ayrıca rutinin lipid peroksidasyonu üzerinde etkili inhibisyon gösterdiği saptanmıştır (Yang, Guo ve Yuan, 2008). Yaygın karabuğdayın rutin açısından zengin olduğu ve önemli derecede antioksidan aktivite gösterdiği belirlenmiştir (Jing ve ark., 2016). Yaygın karabuğdayla kıyaslandığında, Tatar karabuğdayı daha yüksek antioksidan aktiviteye sahiptir (Li, Li ve Ding, 2010). Tatar karabuğdayının özellikle rutin miktarı ile DPPH radikal süpürme aktivitesini arasında pozitif bir korelasyon tespit edilmiştir (Guo ve ark., 2012). Yapılan birçok çalışmada, Tatar karabuğdayı tohumlarının farklı bölümlerinden elde edilen ekstraklarının antioksidan etkinliklere sahip olduğu belirlenmiştir (Guo ve ark., 2012; Ma, Guo, Liu, Xu ve Wang, 2013; Tsai, Deng, Tsai ve Hsu, 2012). Ayrıca, kavurma veya ekstrüzyon gibi işlemlerin, karabuğday unu toplam fenolik içeriğinde ve antioksidan aktivitesinde belirgin bir değişikliğe neden olmadığı saptanmıştır (Şensoy, Rosen, Ho ve Karwe, 2006).

\subsection{Antienflamatuar aktivite}

Yaygın karabuğday filizlerinin etanol ekstraktlarının (ExtBS), hem in vitro hem de in vivo çalışmalarda anti-enflamatuar aktivite gösterdiği belirlenmiştir. ExtBS'nin, LPS (lipopolisakarit) tarafından uyarılan farelerde IL-6 ve $\alpha$-TNF seviyelerinin aşağı regülasyonunu sağladığı tespit edilmiş̧tir. Ayrıca, HeLa hücrelerinde IL-6 ve IL-8'in gen ekspresyonunu doğrudan etkilediği saptanmıştır. Özetle, ExtBS'in, çeşitli enflamatuar hastalıkların ilerlemesini önlemek için kullanılabilme ihtimali üzerinde durulmaktadır (Ishii ve ark., 2008). Yapılan bir çalışmada, Tatar karabuğday filizi ekstraktının anti-enflamatuar etkinliği, LPS ile uyarılmış RAW264.7 hücreleri kullanılarak test edilmiştir. İnterlökin (IL) - 1b, IL-6, nitrik oksit (NO), indüklenebilir nitrik oksit sentaz (iNOS), siklooksijenaz-2 (COX-2) ve tümör nekroz faktörü (TNF- $\alpha$ ) dahil bir dizi pro-enflamatuar sitokin ve enflamatuar araç hedef 


\section{European Journal of Science and Technology}

alınmıştır. Filiz ekstraktlarının LPS ile uyarılmış RAW264.7 hücrelerinde TNF- $\alpha$, IL-6 üretimini inhibe ettiği saptanmıştır. Tatar karabuğdayı ekstraktının, güçlü in vitro anti-enflamatuar aktiviteye sahip olduğu belirlenmiş̧ir (Karki, Park ve Kim, 2013).

\subsection{Hepatoprotektif etki}

Kronik hastalıklara sebep olan karaciğer hasarına, reaktif oksijen ve azot türleri ile alkoller gibi çeşitli kimyasal maddelerin neden olduğu bilinmektedir. Yapılan bir çalışmada, Tatar karabuğday ekstraktının sıçanlarda karbon tetraklorür $\left(\mathrm{CCl}_{4}\right)$ ve etanolün neden olduğu karaciğer hasarı üzerinde koruyucu etkisi olduğu tespit edilmiştir. Ektraktların, süperoksit dismutaz gibi antioksidan enzimlerin aktivitelerini arttırırken, karaciğer ve hepatik iltihaplanmanın bir göstergesi olan serum aspartat aminotransferaz gibi serum içindeki enzim aktivitelerinin artmasını engellediği belirlenmiştir (Lee, Shen, Lai ve Wu, 2013). Tatar karabuğdayında bulunan iki ana polifenol olan rutin ve kuersetinin fareler üzerinde hepatoprotektif etkiye sahip olduğu tespit edilmiştir (Janbaz, Saeed ve Gilani, 2002). Başka bir çalışmada, Tatar karabuğday tohum ekstraktının, $\mathrm{CCl}_{4}$ ve D-galaktosamin tarafından indüklenen akut karaciğer hasarı olan farelerde serum alanin aminotransferaz (ALT) ve aspartat aminotransferaz (AST) aktivitelerini, doza bağlı olarak önemli derecede düşürdüğü gözlemlenmiştir (Kuwabara ve ark., 2008).

\subsection{Antidiyabetik aktivite}

Diyabet dünya genelinde 300 milyondan fazla insanı etkileyen önemli bir sağlık sorunudur. Tatar karabuğdayı geleneksel olarak Çin'de diyabet tedavisinde kullanılmaktadır. Karabuğdayın içerdiği D-chiro-inositolün insülin fonksiyonlarına geçici bir aracılık yaparak kan şekeri seviyesini düşüren insülin benzeri aktiviteye sahip olduğu belirtilmektedir. Tatar karabuğday ekstraktının D-chiroinositol içeriği sayesinde Tip 2 diyabetik sıçanlarda kan glukoz seviyesini düşürerek hipoglisemik etki gösterdiği belirlenmiştir. Tatar karabuğdayı ile beslenen diyabetik hayvanlarda glukagon, trigliserit ve kan üre azotu gibi diğer faktörlerin seviyelerinin düştüğü gözlemlenmiştir. Epidemiyolojik çalışmalar ile diyette Yaygın karabuğday tüketiminin kan şekeri konsantrasyonunu düşürmesi nedeniyle diyabet mellitusun, bir hastalığın toplumda görülme sıklığı olarak tanımlanan prevalansını azaltabileceği tespit edilmiştir (Yao ve ark., 2008; R. Zhang, Xu, Chen ve Zhang, 2010). Polifenoller, sindirim enzimlerine veya nişastaya bağlanarak kan şekeri seviyesini azaltabilmektedir (Zhu, 2016b). Tatar karabuğday ekstresi ve polifenollerinin nişasta sindirim enzimlerine ( $\alpha$-amilaz ve $\alpha$ glikoamilaz) karşı inhibe edici aktiviteler gösterdiği in vitro çalışmalarla belirlenmiştir (Qin, Wu, Yao ve Ren, 2013). Rutin, diyabetik siçanlarda glikoz ve lipidlerin metabolik bozukluğunu düzenleyen ve insülin direncini geliştiren ana biyoaktif bileşen olarak kabul edilmektedir (Liang, Zhang, Kang, Meng ve Yang, 2018).

\subsection{Antibakteriyel aktivite}

Karabuğdayın bazı gıda kaynaklı patojenlere ve in vitro bozulmaya neden olan mikroorganizmalara karşı umut verici antibakteriyel aktiviteler gösterdiği belirlenmiştir. Fagopyrum cymosum etanol ekstraktının, farelerde Hemolytic streptococcus ve Pneumococcus'un büyümesini önemli ölçüde sınırladığı gözlemlenmiştir. Fagopyrum cymosum'un bakteriyostatik aktivitesinden fenolikler ve flavonoidlerin sorumlu olduğu tespit edilmiştir (Jing ve ark., 2016). Tatar karabuğdayından elde edilen ekstraktlardaki kuersetin, isokuersetin ve rutin gibi fenolik bileşiklerin Propionibacterium acnes, Staphylococcus epidermidis ve S. aureus'a karş1 önemli antibakteriyel aktivite gösterdiği belirlenmiştir. Bu fenolik bileşikler arasında da kuersetinin en yüksek antibakteriyel aktiviteye sahip olduğu tespit edilmiştir (Wang, Yang, Qin, Shan ve Ren, 2013).

\subsection{Yorgunluğu önleyici aktivite}

Tatar karabuğday proteininin belirgin bir anti-yorgunluk yeteneğine sahip olduğu belirlenmiştir. Tatar karabuğday ekstraktının, yüzmeye maruz bırakılan erkek Kunming farelerinde yorgunluk önleyici özellik gösterdiği tespit edilmiştir. Farelerde laktik asit ve kandaki üre azotu üretimi azalırken, doku glikojen içeriği ve süperoksit dismutaz ile glutatyon peroksidaz aktivitelerinde artış belirlenmiş̧tir. Karabuğdaydaki antioksidanların, yorgunluğa katkıda bulunan serbest radikalleri temizlemeye yardımcı olduğu sonucuna varılmıştır (Jin ve Wei, 2011).

\section{Karabuğday alerjileri}

Karabuğday taneleri dengeli amino asit bileşimi ile yüksek biyolojik değere sahip protein içermesine rağmen, yeni yapılan araştırmalar bazı karabuğday proteinlerinin alerjik reaksiyonları tetikleyebileceğini göstermektedir. Karabuğday alerjisi ilk olarak literatürde 1909 'da bildirilmiştir. Karabuğday alerjisinin çoğunlukla yer fistı̆̆ alerjisine neden olabilen IgE aracılı reaksiyona benzer olduğu tespit edilmiştir (Tohgi ve ark., 2011). Yapılan araştırmalarda $24 \mathrm{kDa}$ (Fag e 1), 26 kDa ve 67-70 kDa proteinlerinin önemli olduğu birkaç karabuğday alerjeni tanımlanmıştır. $11 \mathrm{~S}$ veya $12 \mathrm{~S}$ globüline homolog olan Fag e 1'in, bütün karabuğday alerjisi olan hastaların serum IgE'si ile reaksiyona girdiği tespit edilmiştir. Sindirime dirençli olan $16 \mathrm{kDa}$ proteini (Fag e 2), karabuğday alerjisi olan Japon ve Koreli hastalarda ana karabuğday alerjeni olarak tanımlanmıştır. Karabuğday ürünlerine alerjinin ana semptomu, tüketimlerinden kısa bir süre sonra ortaya çıkan egzama veya ürtiker olarak belirlenmiş̧ir. Daha ciddi alerjik reaksiyonların anafilaktik şok olarak bilinen kan basıncının hızlı bir şekilde düşmesiyle bağlantılı olarak hemorajik hastalığa neden olabileceği belirtilmiştir (Ahmed ve ark., 2014; Matsuo, Yokooji ve Taogoshi, 2015). 


\section{Sonuç}

Avrupa Bilim ve Teknoloji Dergisi

Karabuğday, tüketimi gün geçtikçe artan ve yüksek ekonomik değere sahip bitkiler arasında kabul edilmektedir. Pseudo-tahıl grubuna dahil olan karabuğday glutensiz gıda kaynağı olarak düşünülmektedir. İçerdiği önemli bileşenler ile özellikle Çin tıbbındaki geleneksel kullanımı dikkat çekmektedir. Geleneksel kullanımları yapılan farmakolojik çalışmalarla doğrulanmaktadır. Karabuğday tohumları temel amino asitler, diyet lifi, mineraller $(\mathrm{Zn}, \mathrm{Fe}, \mathrm{K}$ ve $\mathrm{Mg}$ ), vitaminler $(\mathrm{B}, \mathrm{C}$ ve $\mathrm{E})$, D-chiro-inositol ve polifenoller için önemli bir kaynak olarak kabul edilmektedir. Diyetle birlikte alınan karabuğdayın, dengeli bir beslenme için buğday ve pirinç gibi diğer temel tahıl ürünlerini tamamlayabileceği düşünülmektedir. İçerdiği bileşimin bir sonucu olarak, karabuğdayın, epidemiyolojik incelemenin yanı sıra, in vitro ve in vivo çalışmalarla insan sağlığını olumlu yönde etkileme potansiyeline sahip olduğu belirlenmiştir. $\mathrm{Bu}$ nedenle karabuğday, beslenmemizde yer alması gereken önemli bir gıda olarak değerlendirilmektedir.

\section{Kaynakça}

Anonim. 2019.Buckwheat. http://en.wikipedia. org/wiki/buckwheat (11.06.2019).

Ahmed, A., Khalid, N., Ahmad, A., Abbasi, N. A., Latif, M. S. Z. ve Randhawa, M. A. (2014). Phytochemicals and biofunctional properties of buckwheat: A review. Journal of Agricultural Science, 152(3), 349-369. doi:10.1017/S0021859613000166

Bai, C. Z., Feng, M. L., Hao, X. L., Zhong, Q. M., Tong, L. G. ve Wang, Z. H. (2015). Rutin , quercetin , and free amino acid analysis in buckwheat ( Fagopyrum ) seeds from different locations. Genetics and Molecular Research, 14(4), 19040-19048.

Bayraktar, A. ve Akbulut, G. (2013). Diyabet Mellitus'un Tıbbi Beslenme Tedavisinde Fitik Asit: Faydalı mı? Zararlı mı? Gümüşhane Üniversitesi Sağllk Bilimleri Dergisi, 2(1). doi:10.1034/j.1399-3054.2003.00144.x

Bhinder, S., Singh, B., Kaur, A., Singh, N., Kaur, M., Kumari, S. ve Yadav, M. P. (2019). Effect of infrared roasting on antioxidant activity, phenolic composition and Maillard reaction products of Tartary buckwheat varieties. Food Chemistry, 285(October 2018), 240-251. doi:10.1016/j.foodchem.2019.01.141

Cai, Y., Luo, Q., Sun, M. ve Corke, H. (2004). Antioxidant activity and phenolic compounds of 112 traditional Chinese medicinal plants associated with anticancer. Life Sciences, 74(17), 2157-2184. doi:10.1016/j.lfs.2003.09.047

Chan, P. (2003). Inhibition of tumor growth in vitro by the extract of Fagopyrum cymosum ( fago-c ). Life Sciences, 72, 1851-1858. doi:10.1016/S0024-3205(03)00013-4

Christa, K. ve Soral-Smietana, M. (2008). Buckwheat grains and buckwheat products - Nutritional and prophylactic value of their components - A review. Czech Journal of Food Sciences, 26(3), 153-162.

Dizlek, H., Özer, M. S., İnanç, E. ve Gül, H. (2009). Karabuğday'ın (Fagopyrum Esculentum Moench ) bileşimi ve gıda sanayiinde kullanım olanakları. Gida, 34(5), 317-324.

Dziadek, K., Kopeć, A., Pastucha, E., Piątkowska, E., Leszczyńska, T., Pisulewska, E., ... Francik, R. (2016). Basic chemical composition and bioactive compounds content in selected cultivars of buckwheat whole seeds, dehulled seeds and hulls. Journal of Cereal Science, 69, 1-8. doi:10.1016/j.jcs.2016.02.004

FAOSTAT 2019 Online Database (Erişim adresi: http://www.fao.org/faostat/en/. Erişim tarihi: 15.04.2019)

Giménez-Bastida, J. A., Piskuła, M. ve Zieliński, H. (2015). Recent advances in development of gluten-free buckwheat products. Trends in Food Science and Technology, 44(1), 58-65. doi:10.1016/j.tifs.2015.02.013

Gullón, B., Lú-Chau, T. A., Moreira, M. T., Lema, J. M. ve Eibes, G. (2017). Rutin: A review on extraction, identification and purification methods, biological activities and approaches to enhance its bioavailability. Trends in Food Science and Technology, 67, 220-235. doi:10.1016/j.tifs.2017.07.008

Guo, Xiaona, Zhu, K., Zhang, H. ve Yao, H. (2010). Anti-Tumor Activity of a Novel Protein Obtained from Tartary Buckwheat. International Journal of Molecular Sciences, 11, 5201-5211. doi:10.3390/ijms11125201

Guo, XuDan, Wu, C. Sen, Ma, Y. J., Parry, J., Xu, Y. Y., Liu, H. ve Wang, M. (2012). Comparison of milling fractions of tartary buckwheat for their phenolics and antioxidant properties. Food Research International, 49(1), 53-59. doi:10.1016/j.foodres.2012.07.019

Hayıt, F. ve Gül, H. (2015). Karabuğday’ın Sağlık Açısından Önemi ve Unlu Mamüllerde Kullanımı. Uludă̆ Üniversitesi Ziraat Fakültesi Dergisi, 29(1), 123-132. http://dergipark.gov.tr/ziraatuludag/issue/16765/174324 adresinden erişildi.

Ishii, S., Katsumura, T., Shiozuka, C., Ooyauchi, K., Kawasaki, K., Takigawa, S., .. Ohba, K. (2008). Anti-Inflammatory Effect of Buckwheat Sprouts in Lipopolysaccharide-Activated Human Colon Cancer Cells and Mice. Bioscience, Biotechnology, and Biochemistry, 72(12), 3148-3157. doi:10.1271/bbb.80324

Janbaz, K. H., Saeed, S. A. ve Gilani, A. H. (2002). Protective effect of rutin on paracetamol- and CCl4-induced hepatotoxicity in rodents. Fitoterapia, 73(7-8), 557-563. doi:10.1016/S0367-326X(02)00217-4

Ji, X., Han, L., Liu, F., Yin, S., Peng, Q. ve Wang, M. (2019). A mini-review of isolation, chemical properties and bioactivities of polysaccharides from buckwheat (Fagopyrum Mill). International Journal of Biological Macromolecules, 127, $204-209$. doi:10.1016/j.ijbiomac.2019.01.043

Jin, H. ve Wei, P. (2011). Anti-Fatigue Properties of Tartary Buckwheat Extracts in Mice. International Journal of Molecular Sciences, 12, 4770-4780. doi:10.3390/ijms12084770

Jing, R., Li, H. Q., Hu, C. L., Jiang, Y. P., Qin, L. P. ve Zheng, C. J. (2016). Phytochemical and pharmacological profiles of three Fagopyrum buckwheats. International Journal of Molecular Sciences, 17(4). doi:10.3390/ijms17040589

Kan, A. (2011). Konya Ekolojik Koşullarında Yetiştirilen Karabuğdayın (Fagopyrum Esculentum Moench) Bazı Kalite Özelliklerinin Araştırılması. Selçuk Tarım ve Gida Bilimleri Dergisi, 25(4), 67-71.

Karki, R., Park, C. H. ve Kim, D. W. (2013). Extract of buckwheat sprouts scavenges oxidation and inhibits pro-inflammatory mediators in lipopolysaccharide-stimulated macrophages (RAW264.7). Journal of Chinese Integrative Medicine, 11(4), $246-252$. doi:10.3736/jintegrmed2013036 


\section{European Journal of Science and Technology}

Katar, D., Olgun, M. ve Turan, M. (2016). Analysis of morphological and biochemical characteristics of buckwheat (Fagopyrum Esculentum Moench) in comparison with cereals. CYTA - Journal of Food, 14(2), 176-185. doi:10.1080/19476337.2015.1076522

Kılıç, S. ve Elmacı, Y. (2018). Karabuğday: Bileşimi ve Gıdalarda Kullanılması. Turkish Journal of Agriculture - Food Science and Technology, 6(10), 1388-1401. doi:10.24925/turjaf.v6i10.1388-1401.2038

Kuwabara, T., Han, K.-H., Hashimoto, N., Yamauchi, H., Shımada, K., Sekikawa, M. ve Fukushima, M. (2008). Tartary Buckwheat Sprout Powder Lowers Plasma Cholesterol Level in Rats. Journal of Nutritional Science and Vitaminology, 53(6), 501-507. doi:10.3177/jnsv.53.501

Lee, C. C., Shen, S. R., Lai, Y. J. ve Wu, S. C. (2013). Rutin and quercetin, bioactive compounds from Tartary buckwheat, prevent liver inflammatory injury. Food and Function, 4(5), 794-802. doi:10.1039/c3fo30389f

Li, D., Li, X. ve Ding, X. (2010). Composition and antioxidative properties of the flavonoid-rich fractions from Tartary buckwheat grains. Food Science and Biotechnology, 19(3), 711-716. doi:10.1007/s10068-010-0100-4

Liang, W., Zhang, D., Kang, J., Meng, X. ve Yang, J. (2018). Biomedicine \& Pharmacotherapy Protective effects of rutin on liver injury in type 2 diabetic $\mathrm{db} / \mathrm{db}$ mice. Biomedicine \& Pharmacotherapy, 107(February), 721-728. doi:10.1016/j.biopha.2018.08.046

Ling, A., Li, X., Hu, X., Ma, Z., Wu, K., Zhang, H., ... Wei, S. (2018). Dynamic changes in polyphenol compounds, antioxidant activity, and PAL gene expression in different tissues of buckwheat during germination. Journal of the Science of Food and Agriculture, 98(15), 5723-5730. doi:10.1002/jsfa.9119

Liu, H., Wang, L., Cao, R., Fan, H. ve Wang, M. (2016). In vitro digestibility and changes in physicochemical and structural properties of common buckwheat starch affected by high hydrostatic pressure. Carbohydrate Polymers, 144, 1-8. doi:10.1016/j.carbpol.2016.02.028

Ma, Y. J., Guo, X. D., Liu, H., Xu, B. N. ve Wang, M. (2013). Cooking, textural, sensorial, and antioxidant properties of common and tartary buckwheat noodles. Food Science and Biotechnology, 22(1), 153-159. doi:10.1007/s10068-013-0021-0

Macut, D., Bjekić-Macut, J., Rahelić, D. ve Doknić, M. (2017). Insulin and the polycystic ovary syndrome. Diabetes Research and Clinical Practice, 130, 163-170. doi:10.1016/j.diabres.2017.06.011

Mancini, M., Andreassi, A., Salvioni, M., Pelliccione, F., Mantellassi, G. ve Banderali, G. (2016). Myoinositol and D-Chiro Inositol in Improving Insulin Resistance in Obese Male Children: Preliminary Data. International Journal of Endocrinology, 2016, 1-5. doi: $10.1155 / 2016 / 8720342$

Matsuo, H., Yokooji, T. ve Taogoshi, T. (2015). Common food allergens and their IgE-binding epitopes. Allergology International, 64(4), 332-343. doi:10.1016/j.alit.2015.06.009

Mir, N. A., Riar, C. S. ve Singh, S. (2018). Nutritional constituents of pseudo cereals and their potential use in food systems: A review. Trends in Food Science and Technology, 75(March), 170-180. doi:10.1016/j.tifs.2018.03.016

Mitsunaga, T., Matsuda, M., Shimizu, M. ve Iwashima, A. (1986). İsolation and properties of Thiamine-binding protein from buckwheat seed. Cereal Chemistry, 6(4), 332-335.

Molinari, R., Costantini, L., Timperio, A. M., Lelli, V., Bonafaccia, F., Bonafaccia, G. ve Merendino, N. (2018). Tartary buckwheat malt as ingredient of gluten-free cookies. Journal of Cereal Science, 80, 37-43. doi:10.1016/j.jcs.2017.11.011

Pongrac, P., Potisek, M., Fraś, A., Likar, M., Budič, B., Myszka, K., ... Kreft, I. (2016). Composition of mineral elements and bioactive compounds in Tartary buckwheat and wheat sprouts as affected by natural mineral-rich water. Journal of Cereal Science, 69, 9-16. doi:10.1016/j.jcs.2016.02.002

Qin, P., Wu, L., Yao, Y. ve Ren, G. (2013). Changes in phytochemical compositions, antioxidant and $\alpha$-glucosidase inhibitory activities during the processing of tartary buckwheat tea. Food Research International, 50(2), 562-567. doi:10.1016/j.foodres.2011.03.028

Şensoy, I., Rosen, R. T., Ho, C. T. ve Karwe, M. V. (2006). Effect of processing on buckwheat phenolics and antioxidant activity. Food Chemistry, 99(2), 388-393. doi:10.1016/j.foodchem.2005.08.007

Sieri, S. ve Krogh, V. (2017). Dietary glycemic index, glycemic load and cancer: An overview of the literature. Nutrition, Metabolism and Cardiovascular Diseases, 27(1), 18-31. doi:10.1016/j.numecd.2016.09.014

Tohgi, K., Kohno, K., Takahashi, H., Matsuo, H., Nakayama, S. ve Morita, E. (2011). Usability of Fag e 2 ImmunoCAP in the diagnosis of buckwheat allergy. Archives of Dermatological Research, 303(9), 635-642. doi:10.1007/s00403-011-1142-z

Tsai, H., Deng, H., Tsai, S. ve Hsu, Y. (2012). Bioactivity comparison of extracts from various parts of common and tartary buckwheats: evaluation of the antioxidant- and angiotensin-converting enzyme inhibitory activities. Chemistry Central Journal, 6(1), 1. doi:10.1186/1752-153X-6-78

Wajid, M., Aslam, M. S. ve Uzair, M. (2015). Genus Fagopyrum: Phytochemical and Ethnopharmacological Review. Indian Research Journal of Pharmacy and Science, 2(2), 1-14.

Wang, L., Yang, X., Qin, P., Shan, F. ve Ren, G. (2013). Flavonoid composition , antibacterial and antioxidant properties of tartary buckwheat bran extract. Industrial Crops \& Products, 49, 312-317. doi:10.1016/j.indcrop.2013.04.039

Wijngaard, H. H. ve Arendt, E. K. (2006). Buckwheat. Cereal Chemistry, 83(4), 391-401. doi:10.1201/9780203711248

Yang, J., Guo, J. ve Yuan, J. (2008). In vitro antioxidant properties of rutin. LWT - Food Science and Technology, 41(6), 1060-1066. doi:10.1016/j.lwt.2007.06.010

Yao, Y., Shan, F., Bian, J., Chen, F., Wang, M. ve Ren, G. (2008). D-chiro-inositol-enriched tartary buckwheat bran extract lowers the blood glucose level in KK-Ay mice. Journal of agricultural and food chemistry, 56(21), 10027-10031.

Yiming, Z., Hong, W., Linlin, C., Xiaoli, Z., Wen, T. ve Xinli, S. (2015). Evolution of nutrient ingredients in tartary buckwheat seeds during germination. Food Chemistry, 186, 244-248. doi:10.1016/j.foodchem.2015.03.115

Yıldız, N. ve Yalçın, E. (2013). Karabuğdayın Kimyasal, Besinsel ve Teknolojik özellikleri. Glda, 38(6), 383-390. doi:10.5505/gida.2013.43153

Zhang, R., Xu, G., Chen, W. ve Zhang, W. (2010). Genetic Polymorphisms of Glutathione S -Transferase P1 and Bladder Cancer Susceptibility in a Chinese Population . Genetic Testing and Molecular Biomarkers, 15(1-2), 85-88. doi:10.1089/gtmb.2010.0162 


\section{Avrupa Bilim ve Teknoloji Dergisi}

Zhang, Z. L., Zhou, M. L., Tang, Y., Li, F. L., Tang, Y. X., Shao, J. R., ... Wu, Y. M. (2012). Bioactive compounds in functional buckwheat food. Food Research International, 49(1), 389-395. doi:10.1016/j.foodres.2012.07.035

Zheng, C., Hu, C., Ma, X., Peng, C., Zhang, H. ve Qin, L. (2012). Cytotoxic phenylpropanoid glycosides from Fagopyrum Tataricum (L.) Gaertn. Food Chemistry, 132(1), 433-438. doi:10.1016/j.foodchem.2011.11.017

Zhu, F. (2016a). Buckwheat starch: Structures, properties, and applications. Trends in Food Science and Technology, 49, 121-135. doi:10.1016/j.tifs.2015.12.002

Zhu, F. (2016b). Chemical composition and health effects of Tartary buckwheat. Food Chemistry, 203, 231-245. doi:10.1016/j.foodchem.2016.02.050 